\title{
On the Cascading of Dense Shelf Waters in the Irminger Sea
}

\author{
ANASTASIA FALINA AND ARTEM SARAFANOV \\ P.P. Shirshov Institute of Oceanology, Moscow, Russia \\ HERLÉ MERCIER \\ CNRS, Laboratoire de Physique des Océans, Plouzané, France \\ PASCALE LHERMINIER \\ Ifremer, Laboratoire de Physique des Océans, Plouzané, France \\ AlEXEY SOKOV \\ P.P. Shirshov Institute of Oceanology, Moscow, Russia \\ NATHALIE DANIAULT \\ UBO, Laboratoire de Physique des Océans, Brest, France
}

(Manuscript received 16 January 2012, in final form 25 July 2012)

\begin{abstract}
Hydrographic data collected in the Irminger Sea in the 1990s-2000s indicate that dense shelf waters carried by the East Greenland Current south of the Denmark Strait intermittently descend (cascade) down the continental slope and merge with the deep waters originating from the Nordic Seas overflows. Repeat measurements on the East Greenland shelf at $\sim 200 \mathrm{~km}$ south of the Denmark Strait $\left(65^{\circ}-66^{\circ} \mathrm{N}\right)$ reveal that East Greenland shelf waters in the Irminger Sea are occasionally as dense $\left(\sigma_{0}>27.80\right)$ as the overflow-derived deep waters carried by the Deep Western Boundary Current (DWBC). Clear hydrographic traces of upstream cascading of dense shelf waters are found over the continental slope at $64.3^{\circ} \mathrm{N}$, where the densest plumes $\left(\sigma_{0}>\right.$ 27.80 ) originating from the shelf are identified as distinct low-salinity anomalies in the DWBC. Downstream observations suggest that dense fresh waters descending from the shelf in the northern Irminger Sea can be distinguished in the DWBC up to the latitude of Cape Farewell $\left(\sim 60^{\circ} \mathrm{N}\right)$ and that these waters make a significant contribution to the DWBC transport.
\end{abstract}

\section{Introduction}

Cooling of the upper-ocean waters in the subpolar North Atlantic and the Arctic Mediterranean produces dense waters that flow equatorward in the lower limb of the meridional overturning circulation. One of the crucial sites for the overturning circulation is the Irminger Sea (Fig. 1), where the Atlantic and Arctic water masses join in an intense southwestward flowing Western Boundary Current (WBC) extending from the sea surface

Corresponding author address: Anastasia Falina, P.P. Shirshov Institute of Oceanology, 36, Nakhimovskiy Prospect, 117997 Moscow, Russia.

E-mail: falina_a@mail.ru to the bottom along the shelf and continental slope of Greenland (Fig. 1). The upper part of the WBC $\left(\sigma_{0}<\right.$ 27.80), which is often referred to as the East Greenland/ Irminger Current (e.g., Lherminier et al. 2007, 2010; Sarafanov et al. 2012), carries (i) cold and fresh upperocean waters advected from the Greenland Sea through the Denmark Strait by the East Greenland Current (EGC) (e.g., Sutherland and Pickart 2008), (ii) warm and saline North Atlantic waters recirculating cyclonically from the eastern Irminger Sea and Iceland Basin (e.g., Lherminier et al. 2010; Sarafanov et al. 2012), and (iii) Labrador Sea Water (LSW) - a relatively fresh intermediate water mass formed by deep convection in the Labrador Sea (e.g., Lazier et al. 2002) and, occasionally, in the Irminger Sea (Nansen 1912; Pickart et al. 2003; 
Falina et al. 2007; Våge et al. 2011a). The lower part of the WBC $\left(\sigma_{0}>27.80\right)$, commonly referred to as the Deep WBC (DWBC), carries the deep water masses formed by mixing of cold and dense Nordic Sea overflow waters with warmer and lighter Atlantic waters (e.g., Dickson and Brown 1994).

The origin and hydrographic variability of the intermediate and deep waters carried by the WBC in the Irminger Sea were recently the subject of increased attention (e.g., Rudels et al. 1999, 2002; Dickson et al. 2002; Pickart et al. 2003, 2005; Holfort and Albrecht 2007; Falina et al. 2007; Yashayaev et al. 2007; Yashayaev and Dickson 2008; Sarafanov 2009; Sarafanov et al. 2010, 2012; Våge et al. 2011a,b; Brearley et al. 2012). In particular, it was shown that in the northern Irminger Sea, south of the Denmark Strait, cold and fresh upper-ocean waters transported by the EGC over the shelf occasionally descend (cascade) down the continental slope and affect the thermohaline properties and dynamics of the WBC at the intermediate levels (Rudels et al. 1999, 2002; Pickart et al. 2005; Magaldi et al. 2011; Brearley et al. 2012). Cascading of shelf waters was shown to be at the origin of the socalled East Greenland Spill Jet-a localized bottomintensified flow observed in the northern Irminger Sea in the WBC above the DWBC (see Pickart et al. 2005). A contribution of shelf water cascading south of the Denmark Strait to the formation and variability of deep waters transported by the DWBC $\left(\sigma_{0}>27.80\right)$ was hypothesized by Rudels et al. (1999) and Brearley et al. (2012).

In the present study based on hydrographic data collected in the western Irminger Sea in the 1990s-2000s, we present new findings supporting the hypothesis (Rudels et al. 1999) that dense waters cascading from the East Greenland shelf southwest of the Denmark Strait occasionally merge with the overflow-derived deep waters carried by the DWBC. We also suggest that hydrographic traces of shelf water cascading can be found in the DWBC as far downstream as $60^{\circ} \mathrm{N}$ and make a first estimate of the transient contribution of a cascading event to the DWBC transport.

The paper is organized as follows. In section 2, we briefly describe the origin and properties of the deep waters in the Irminger Sea and summarize the present-day knowledge of shelf water cascading south of the Denmark Strait. The hydrographic data used in the study are described in section 3 . In section 4, we discuss the hydrographic properties of the deep waters east of Cape Farewell in the southern Irminger Sea and the probable origins of the anomalously fresh and highly oxygenated plumes observed in the DWBC. In section 5, we demonstrate that in the northern Irminger Sea, in the vicinity of the Denmark Strait, shelf waters are occasionally dense enough to cascade down the slope and join the DWBC.
Observations supporting the occurrence of such cascading are presented in section 6 . The imprint of the shelf water cascading on the hydrographic properties of the DWBC waters in the southern Irminger Sea is discussed in section 7. An estimate of the transient contribution of shelf water cascading in the northern Irminger Sea to the DWBC transport at Cape Farewell is made in section 8. Conclusions are drawn in section 9.

\section{Background: Deep waters in the Irminger Sea and potential contribution of shelf water cascading to their formation}

The deep water column in the Irminger Sea is occupied by the waters originating from the Nordic Sea overflows that entrained Atlantic waters downstream of the sills to form the Iceland-Scotland Overflow Water (ISOW) and Denmark Strait Overflow Water (DSOW) (e.g., Dickson and Brown 1994) (Fig. 1).

The ISOW in the Irminger Sea has potential density of $27.80<\sigma_{0}<27.88$, potential temperature $(\theta)$ of $2.7-$ $2.9^{\circ} \mathrm{C}$, salinity $(S)$ of over 34.90 and dissolved oxygen concentrations of $275-280 \mu \mathrm{mol} / \mathrm{kg}$ (Fogelqvist et al. 2003; Sarafanov et al. 2012). The export of the ISOW from the Irminger Sea is thought to occur in the DWBC, which is commonly defined as the lower part of the WBC transporting waters denser than $\sigma_{0}=27.80$ (e.g., Dickson and Brown 1994; Bacon 1998; Keike and Rhein 2006; Sarafanov et al. 2009, 2012). The recent study by Sarafanov et al. (2012) suggests, however, that in the 2000s the ISOW outflow from the Irminger Sea occurred largely in the interior part of the basin rather than in the DWBC, which was fed primarily by the DSOW and by the diapycnal flux from the upper levels.

At the exit of the Irminger Sea, in the vicinity of Cape Farewell $\left(\sim 60^{\circ} \mathrm{N}\right)$, the DSOW has the following properties: $\theta<2^{\circ} \mathrm{C}, S \sim 34.9$, and $\sigma_{0}>27.88$ (e.g., Holliday et al. 2009; Keike and Rhein 2006). It is commonly accepted that the Nordic component of the DSOW enters the Irminger Sea through the deepest channel of the Denmark Strait (Smith 1976; Dickson and Brown 1994; Käse et al. 2003; Girton and Sanford 2003; Macrander et al. 2005; Tanhua et al. 2005). Recent observations in the Denmark Strait (Rudels et al. 2002; Våge et al. 2011b; Brearley et al. 2012) showed, however, that the dense waters $\left(\sigma_{0}>27.80\right)$ pass through the Denmark Strait not only via its deepest channel but also over the East Greenland shelf.

Whether the dense shelf waters join the "classical" overflow south of the Denmark Strait remains an open question. Based on hydrographic observations immediately south of the Denmark Strait, Rudels et al. (1999, 2002) hypothesized that the densest shelf waters transported by the EGC (Fig. 1) could descend down the East 


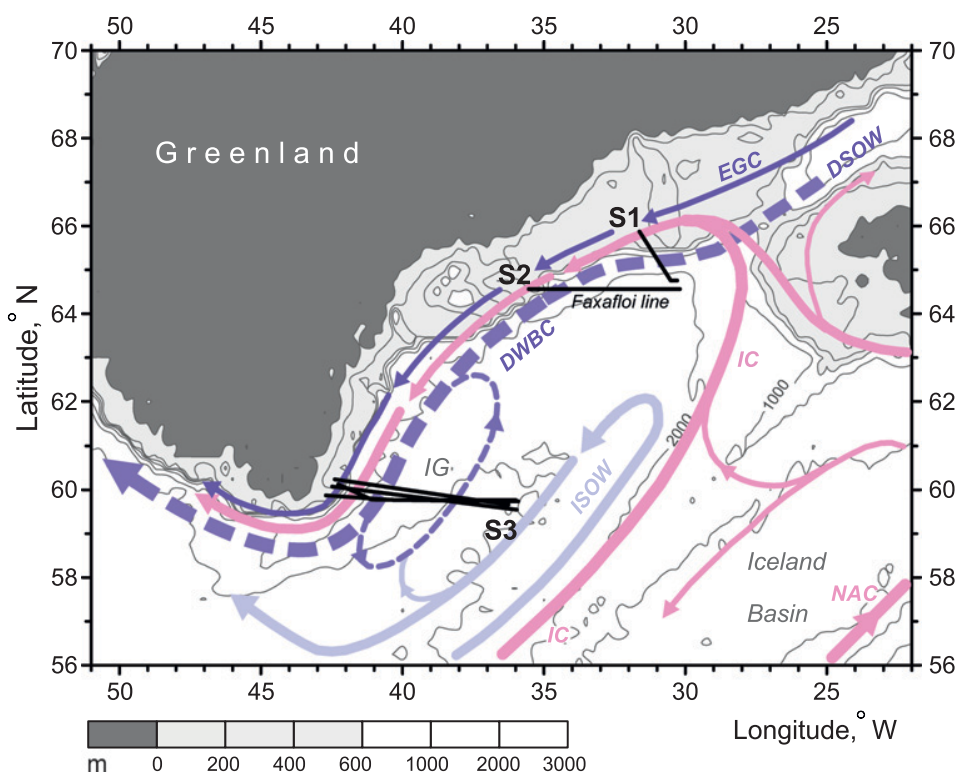

\begin{tabular}{|l|}
\hline S1 line: \\
R/V Meteor, 1997, 1999, 2003 \\
R/V Valdivia, 1998 \\
R/V Poseidon, 2000 \\
R/V Arni Fridriksson, 2005 \\
S2 line: \\
R/V Bjarni Saemundsson - \\
11 repeats, 1997 - 2003 \\
S3 line: \\
R/V Professor Shtokman, 1997 \\
R/V Meteor, 1999 \\
R/V Poseidon, 2000 \\
R/V Thalassa, 2002, 2004 \\
R/V Maria S. Merian, 2006 \\
R/V Pelagia, 2000, 2003, 2005 \\
R/V Akademik Mstislav Keldysh, 2002 \\
R/V Akademik loffe, 2004, 2006, \\
2007, 2008, 2009
\end{tabular}

FIG. 1. Locations of the repeat hydrographic sections used in the study. General pathways of the Nordic Sea overflow-derived deep waters (DSOW and ISOW), the EGC, DWBC, Irminger Current (IC), and North Atlantic Current (NAC) are schematically visualized (see Sarafanov et al. 2012). IG is Irminger Gyre (see Våge et al. 2011a). The depths of less than $600 \mathrm{~m}$ are shaded.

Greenland slope in the northern Irminger Sea and merge with the DSOW flow $\left(\sigma_{0}>27.80\right)$. However, a subsequent analysis by Pickart et al. (2005) did not reveal descending shelf waters dense enough to join the DSOW. Instead, these waters were suggested to form the East Greenland Spill Jet carrying waters lighter than DSOW (Pickart et al. 2005; Magaldi et al. 2011). Most recently, Brearley et al. (2012) demonstrated that the East Greenland Spill Jet occasionally transports waters denser than $\sigma_{0}=27.80$.

The shelf water cascading in the Irminger Sea is likely to be an episodic and localized phenomenon, which temporal and spatial scales cannot be fully resolved by available hydrographic data. Therefore, it is likely that the studies by Rudels et al. (1999, 2002), Pickart et al. (2005) and Brearley et al. (2012), which were based on data from few hydrographic surveys, documented different stages and manifestations of the phenomenon, and this led to different inferences about what components of the WBC system are affected by waters descending from the shelf.

\section{Data}

We used the 1997-2009 temperature and salinity (CTD) profiles from 32 repeats of 3 hydrographic sections in the northwestern and southwestern Irminger Sea (Fig. 1, Table 1). The 6 repeats of the northernmost section at $65^{\circ}-66^{\circ} \mathrm{N}(1997-2005, \mathrm{~S} 1$ in Fig. 1) were carried out in summer (July-August). The 11 repeats of the $64.3^{\circ} \mathrm{N}$ section (1997-2003, Faxafloi section, S2 in Fig. 1) were carried out in winter-spring (November-May) (Dickson et al. 2008). In the southwestern Irminger Sea, the data were from 15 surveys conducted in summer-fall (June-October) along the nearly collocated $59.5^{\circ} \mathrm{N}$ section (e.g., Falina et al. 2007; Sarafanov et al. 2007, 2010, 2012), Ovide section (e.g., Lherminier et al. 2007, 2010) and the AR7E line (e.g., Våge et al. 2011a) (1997-2009, S3 in Fig. 1). In addition to the CTD profiles, we used the June 2002 and 2004 oxygen data from the CTD- $\mathrm{O}_{2}$ probe at the Ovide section. These data were calibrated with oxygen concentrations obtained from water samples. The accuracies of the temperature, salinity, and oxygen were estimated at $0.001^{\circ}-0.002^{\circ} \mathrm{C}, 0.002-0.003$, and better than $2 \mu \mathrm{mol} \mathrm{kg}{ }^{-1}$, respectively. The quality of all hydrographic data meets the World Ocean Circulation Experiment standards.

\section{Probable origins of low-salinity anomalies in the DWBC at $\sim 60^{\circ} \mathrm{N}$}

The initial motivation of this study was finding an explanation for the strong thermohaline variability of the deep waters at Cape Farewell. Therefore, prior to focusing on the shelf waters and the signatures of their cascading in the northern Irminger Sea, we consider the thermohaline structure of the deep waters carried by the DWBC at $\sim 60^{\circ} \mathrm{N}$. 
TABLE 1. List of cruises used in the study.

\begin{tabular}{|c|c|}
\hline Date & Vessel \\
\hline \multicolumn{2}{|c|}{ Line $\mathrm{S} 1\left(64.5^{\circ}-66^{\circ} \mathrm{N}\right)$} \\
\hline August 1997 & Meteor \\
\hline August 1998 & Valdivia \\
\hline August 1999 & Meteor \\
\hline August 2000 & Poseidon \\
\hline July 2003 & Meteor \\
\hline August 2005 & Árni Friðriksson \\
\hline \multicolumn{2}{|c|}{ Line S2 $\left(64.3^{\circ} \mathrm{N}\right)$} \\
\hline May 1997 & Bjarni Saemundsson \\
\hline December 1997 & Bjarni Saemundsson \\
\hline February 1998 & Bjarni Saemundsson \\
\hline May 1998 & Bjarni Saemundsson \\
\hline November 1998 & Bjarni Saemundsson \\
\hline February 1999 & Bjarni Saemundsson \\
\hline May 1999 & Bjarni Saemundsson \\
\hline November 1999 & Bjarni Saemundsson \\
\hline May 2001 & Bjarni Saemundsson \\
\hline May 2002 & Bjarni Saemundsson \\
\hline May 2003 & Bjarni Saemundsson \\
\hline \multicolumn{2}{|c|}{ Line $S 3\left(\sim 60^{\circ} \mathrm{N}\right)$} \\
\hline October 1997 & Professor Shtokman \\
\hline August 1999 & Meteor \\
\hline August 2000 & Poseidon \\
\hline October 2000 & Pelagia \\
\hline June 2002 & Thalassa \\
\hline August 2002 & Akademik Mstislav Keldysh \\
\hline August 2003 & Pelagia \\
\hline July 2003 & Meteor \\
\hline June 2004 & Thalassa \\
\hline June 2004 & Akademik Ioffe \\
\hline September 2005 & Pelagia \\
\hline June 2006 & Maria S. Merian \\
\hline July 2007 & Akademik Ioffe \\
\hline June 2008 & Akademik Ioffe \\
\hline September 2009 & Akademik Ioffe \\
\hline
\end{tabular}

The $\theta-S$ diagrams (Fig. 2) from the southwestern Irminger Sea (the S3 line in Fig. 1) reveal two prominent types of deep water $\left(\sigma_{0}>27.80\right)$ thermohaline structure. In $60 \%$ of the cases ( 9 surveys out of 15 , Fig. $2 a$ ), the salinity exhibits a distinct maximum in the ISOW density class $\left(27.80<\sigma_{0}<27.88\right)$ and gradually decreases toward the bottom; for a given survey, the DSOW layer $\left(\sigma_{0}>27.88\right)$ is nearly constant in salinity. In $40 \%$ of the cases ( 6 surveys out of 15 , Figs. $2 \mathrm{~b}, \mathrm{c}$ ), the $\theta-S$ diagrams show either widely scattered $\theta-S$ indices in the entire deep water layer $\left(\sigma_{0}>27.80\right)$ (Fig. $\left.2 \mathrm{c}\right)$ or the presence of two distinct deep water masses separated by at least 0.02 in salinity, with nearly no mixing between them (Fig. 2b). The only explanation of these disturbances in the observed deep water structure is an upstream injection of anomalously fresh dense waters. The Ovide data demonstrate that these fresh $(34.84<S<34.88)$ a)

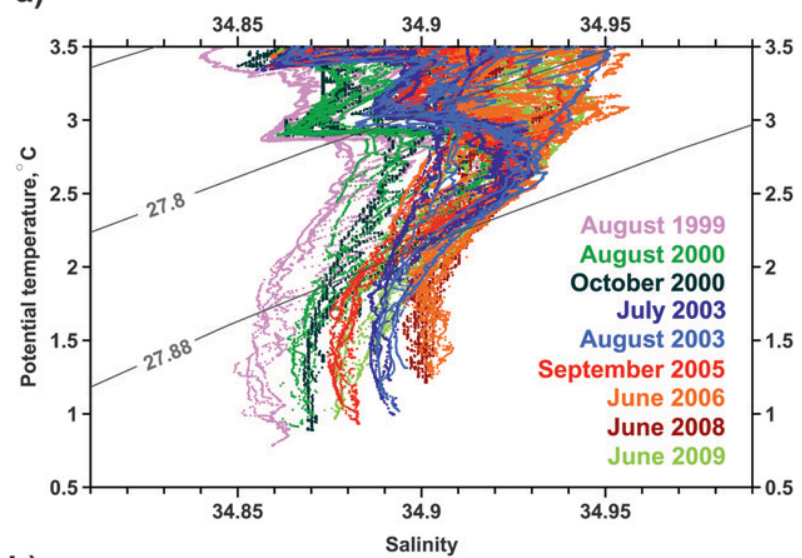

b)

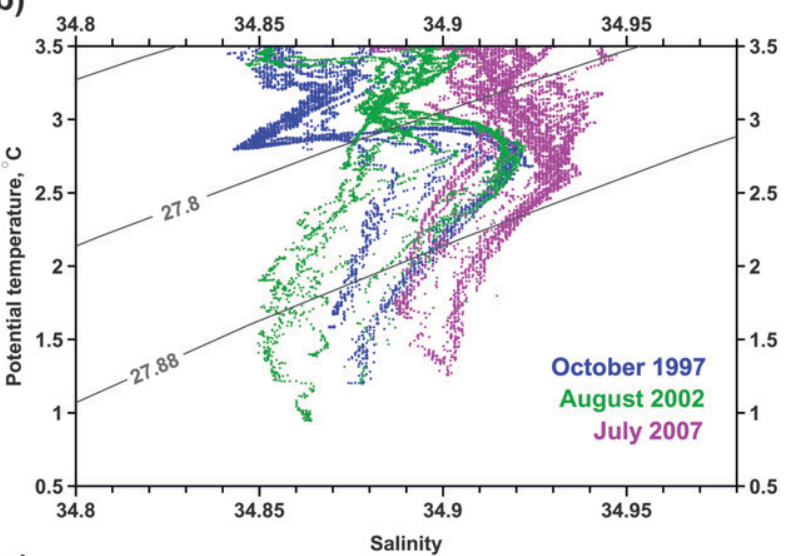

c)

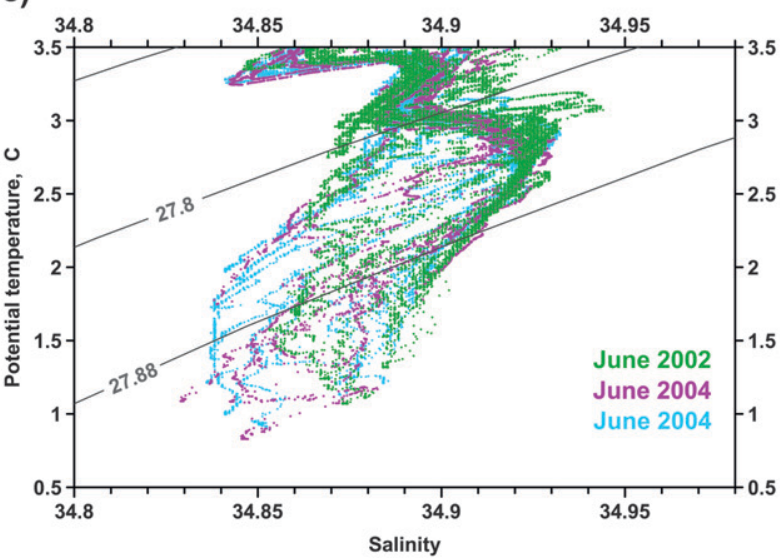

FIG. 2. The $\theta-S$ diagrams for the data collected in the southern Irminger Sea at $\sim 60^{\circ} \mathrm{N}$ (the S3 line in Fig. 1) in 1997-2009. The plots illustrate different types of the deep water $\left(\sigma_{0}>27.80\right)$ thermohaline structure as discussed in section 4.

waters are localized at the East Greenland slope in the ISOW density class $\left(27.80<\sigma_{0}<27.88\right)$ at depths of $\sim 1500-2400$ m (Figs. 3a,c). Remarkably, the oxygen concentrations in these waters $\left(290<\mathrm{O}_{2}<305 \mu \mathrm{mol} \mathrm{kg}{ }^{-1}\right.$, Figs. 3b,d) are close to those in the DSOW layer (290$\left.310 \mu \mathrm{mol} \mathrm{kg} \mathrm{kg}^{-1}, \sigma_{0}>27.88\right)$ and are substantially 
a)

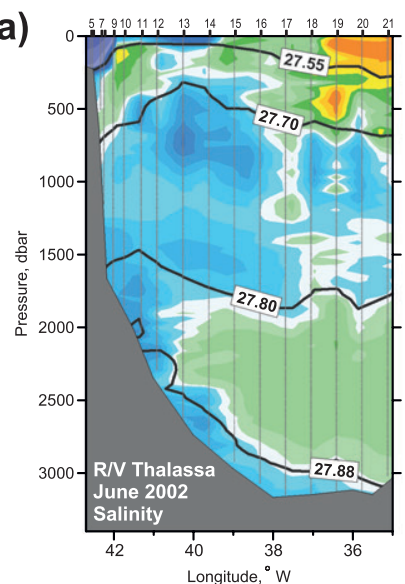

c)

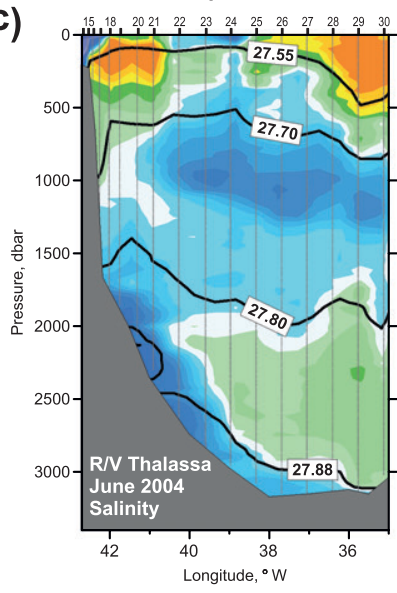

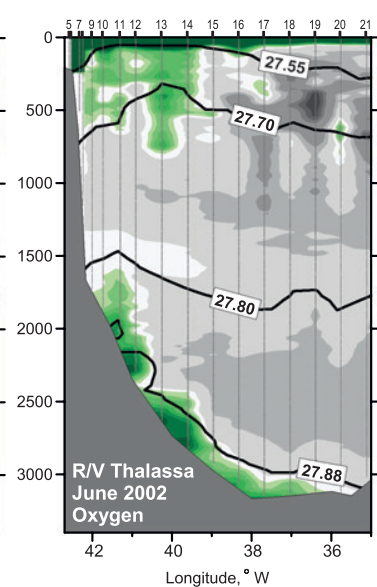

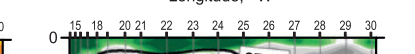

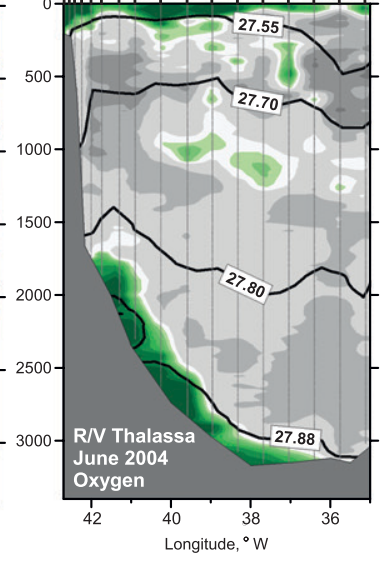

b)

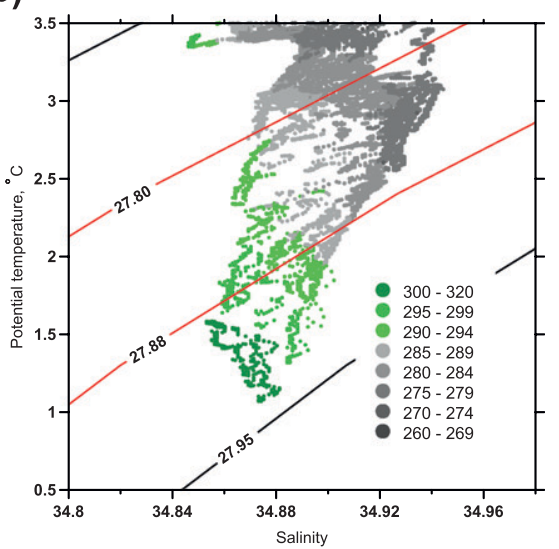

d)

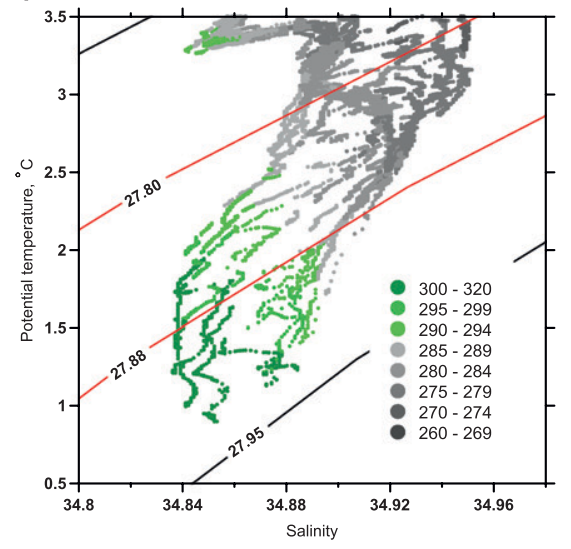

$\mathrm{O}_{2}, \mu \mathrm{moll} k \mathrm{~kg}$

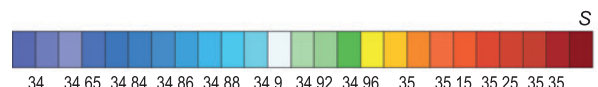
$240 \quad 250 \quad 255260265270275 \quad 280287290 \quad 292 \quad 294 \quad 296 \quad 298 \quad 300 \quad 302$

e)
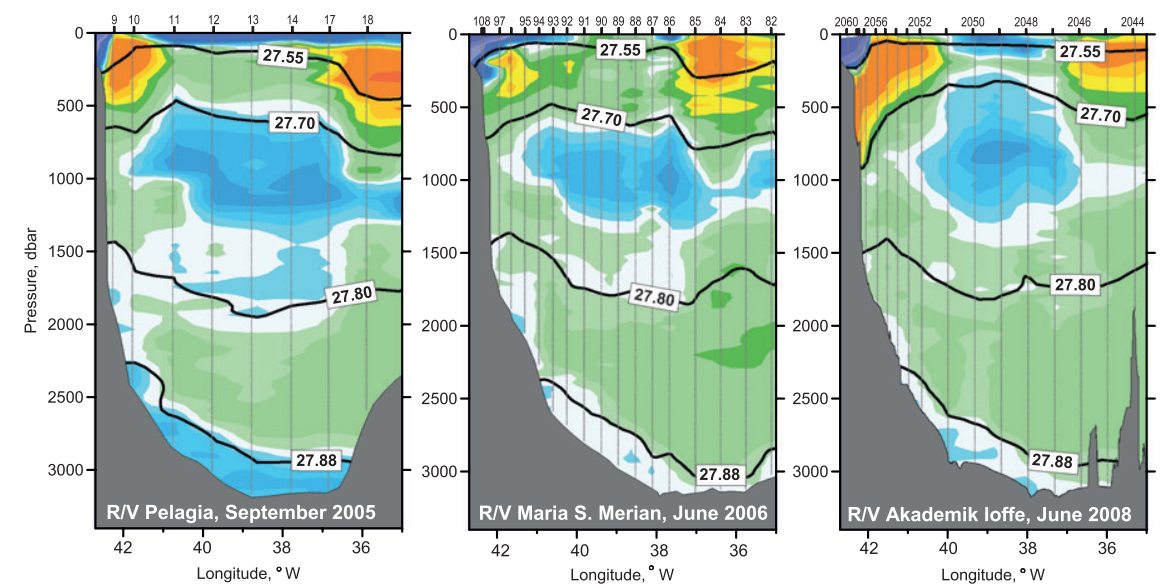

FIG. 3. Salinity and oxygen concentrations ( $\mu \mathrm{mol} \mathrm{kg}^{-1}$ ) observed at $\sim 60^{\circ} \mathrm{N}$ in (a) June 2002 and (c) June 2004. The $\sigma_{0}$ isopycnals $27.55,27.70,27.80$, and 27.88 are shown as thick black lines; the station locations are marked with the ticks on the top axes. $\theta-S-\mathrm{O}_{2}$ diagrams for the (b) June 2002 and (d) June 2004 data. (e) Salinity observed at $\sim 60^{\circ} \mathrm{N}$ in September 2005, June 2006, and 2008. Figs. 3a-d illustrate the occasional presence of anomalously fresh and oxygenated near-slope waters in the ISOW density class $\left(27.80<\sigma_{0}<27.88\right)$, while the plots in Fig. 3e refer to the situation when no such distinct features were observed. 
higher than the concentrations typical for ISOW (275$\left.285 \mu \mathrm{mol} \mathrm{kg}{ }^{-1}, 27.80<\sigma_{0}<27.88\right)$ and the deep LSW (275-288 $\left.\mu \mathrm{mol} \mathrm{kg}{ }^{-1}, 27.76<\sigma_{0}<27.80\right)$. For reference, we show in Fig. 3e three salinity patterns typical for the situation (see Fig. 2a) when no distinct heterogeneities are found in the deep water column.

The question is what mechanism(s) can explain the occasional presence of the anomalously fresh and oxygenated waters in the ISOW density class and the remarkable associated heterogeneities in the entire deep water layer $\left(\sigma_{0}>27.80\right)$ at the East Greenland slope at $\sim 60^{\circ} \mathrm{N}$. Two mechanisms can be suggested.

1) The anomalies originate from the Denmark Strait Overflow. Being injected into the Irminger Sea through the deepest part of the Denmark Strait sill, the anomalies are carried by the DWBC along the slope (e.g., Holfort and Albrecht 2007; Yashayaev and Dickson 2008). Despite an intense mixing of the overflow waters with warmer, saltier, and less oxygenated ambient waters (e.g., Dickson and Brown 1994), the fresh high-oxygen plumes retain their anomalous properties along the entire pathway from the Denmark Strait sill to $60^{\circ} \mathrm{N}$. This would occur in $40 \%$ of the cases (see above), while for the other $60 \%$ either no such plumes are injected through the Denmark Strait sill or the plumes "disappear" because of vigorous mixing and do not reach $60^{\circ} \mathrm{N}$.

2) The anomalies originate from dense waters $\left(\sigma_{0}>27.80\right)$ episodically injected, over the shelf, by the EGC through the Denmark Strait into the Irminger Sea (Rudels et al. 2002; Våge et al. 2011b; Brearley et al. 2012). South of the Strait, the dense shelf waters propagate southwestwards, fall down the East Greenland slope, and merge with the overflow-derived waters, as hypothesized by Rudels et al. (1999; 2002). Then, the shelf water-derived fresh oxygenated plumes are transported by the DWBC from cascading site(s) to $\sim 60^{\circ} \mathrm{N}$.

The two mechanisms do not exclude each other. The first one corresponds to the classical paradigm. The second one is supported by the advection of dense shelf waters $\left(\sigma_{0}>27.80\right)$ by the EGC through the Denmark Strait. However, the cascading of shelf waters down to the layer of the overflow-derived deep waters transported by the DWBC has not been sufficiently documented. Below, we inspect the data collected in the northwestern Irminger Sea at $64^{\circ}-66^{\circ} \mathrm{N}$ (the S1 and S2 lines in Fig. 1) and identify signatures of such cascading.

\section{Dense shelf waters southwest of the Denmark Strait}

Hydrographic data collected at $\sim 200 \mathrm{~km}$ southwest of the Denmark Strait at $65^{\circ}-66^{\circ} \mathrm{N}$ (the S1 line in Fig. 1) confirm that waters on the East Greenland shelf in the northwestern Irminger Sea are occasionally denser than $\sigma_{0}=27.80$. Figures $4 \mathrm{a}$ and $4 \mathrm{c}$ show the potential density, temperature, and salinity distributions at S1 in August 2005 and July 2003. In August 2005, dense $\left(\sigma_{0}>27.80\right)$ cold fresh waters were found at depths of $260-370 \mathrm{~m}$ at three stations carried out over the shelf (stations 65, 67 and 68). At station 68, the density of the near-bottom waters was up to $\sigma_{0}=27.889$ (Figs. 4a,b). In July 2003, dense (up to $\sigma_{0}=27.865$ ) shelf waters were found at the westernmost station 422 (Figs. $4 \mathrm{c}, \mathrm{d}$ ).

Potential temperature $\left(1.17^{\circ}<\theta<1.9^{\circ} \mathrm{C}\right)$ and density $\left(\sigma_{0}>27.80\right)$ of the near-bottom shelf waters observed in 2003 and 2005 are similar to those of the overflow water passing through the deepest channel of the Denmark Strait $\left(\theta<2^{\circ} \mathrm{C}, \sigma_{0}>27.80\right)$ (Tanhua et al. 2005). Salinity of the dense shelf waters $(34.75<S<34.83)$ is substantially lower than the typical salinity of the overflow in the deepest channel of the Denmark Strait $(34.87<S<34.94)$ (e.g., Dickson et al. 2002, their Fig. 2 ). In the $\theta-S$ plane (Fig. 5), the thermohaline indices of the densest shelf waters (referred to as "DSW" in Fig. 5) observed at S1 in August 2005 lie on a mixing line between the cold and fresh Polar Intermediate Water (see Rudels et al. 1999) and the warm and saline waters of the Irminger Current observed in the northern part of the Irminger Sea (see Fogelqvist et al. 2003). This agrees with the suggestion by Rudels et al. (2002) that the latter two water types are the main components of the dense shelf waters south of the Denmark Strait.

The presence of the dense $\left(27.80<\sigma_{0}<27.89\right)$ waters over the East Greenland shelf at S1 was revealed in the 2003 and 2005 repeats of the section, which present a better sampling of the shelf (4 stations in 2003 and 6 stations in 2005, see Fig. 4) than the 1997-2000 repeats, when only one station in each cruise was carried out over the shelf. Therefore, given the large width of the shelf at $\mathrm{S} 1(\sim 150 \mathrm{~km})$, it is possible that the dense shelf waters were missed in the 1997-2000 data because of insufficient sampling over the shelf.

It is very likely that the dense shelf waters observed at S1 were advected into the Irminger Sea by the EGC through the Denmark Strait, where the shelf waters with similar properties $\left(\theta<2^{\circ} \mathrm{C}, \sigma_{0}>27.80\right)$ were repeatedly observed (see Rudels et al. 2002; Brearley et al. 2012; Våge et al. 2011b). Based on data from a single synoptic survey in the Denmark Strait, Brearley et al. (2012) reported on the dense water transport $\left(\sigma_{0}>27.80\right)$ of about $1 \mathrm{~Sv}\left(1 \mathrm{~Sv} \equiv 10^{6} \mathrm{~m}^{3} \mathrm{~s}^{-1}\right)$ on the East Greenland shelf. Accordingly, a part of the dense water transport $\left(\sigma_{0}>27.80\right)$ through the Denmark Strait to the North Atlantic is likely to be missing in the existing estimates (e.g., 
a)

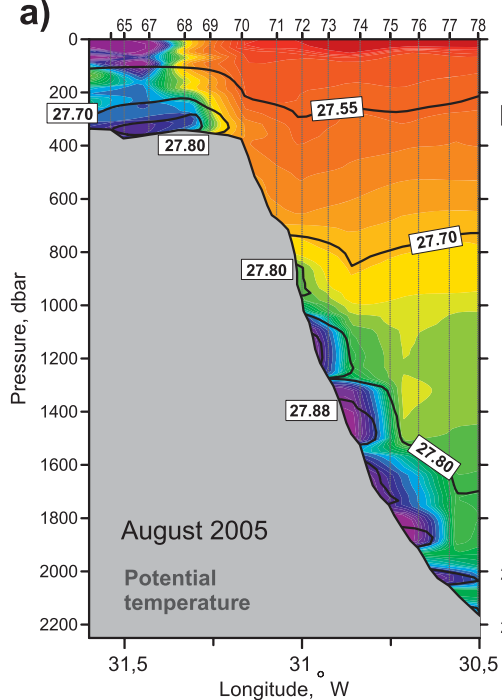

C) $\quad 422423424425426427428429430431432$

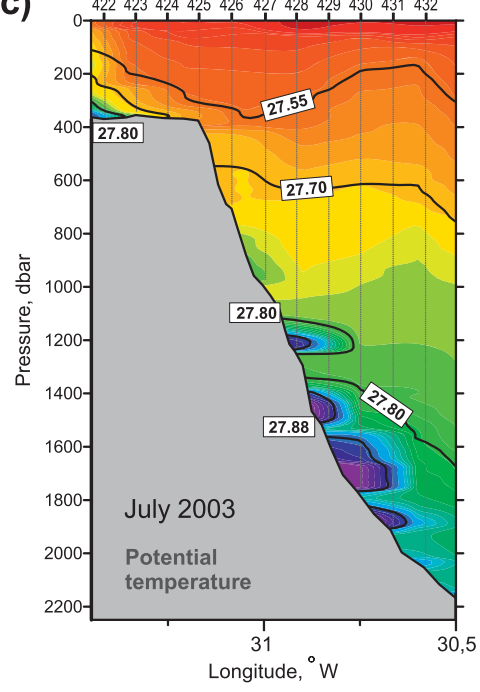

T.

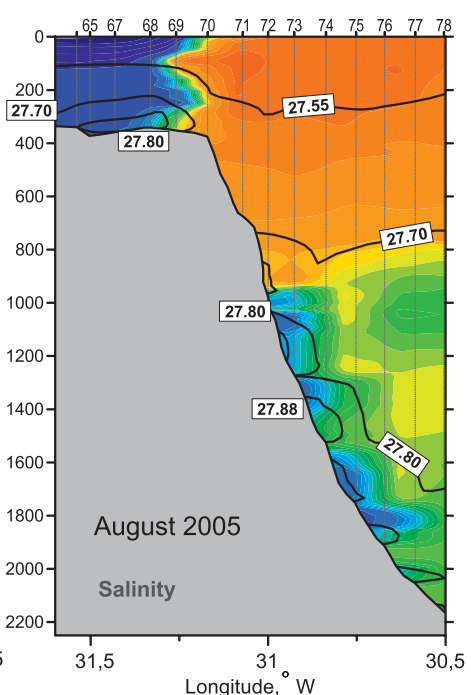

422423424425426427428429430431432

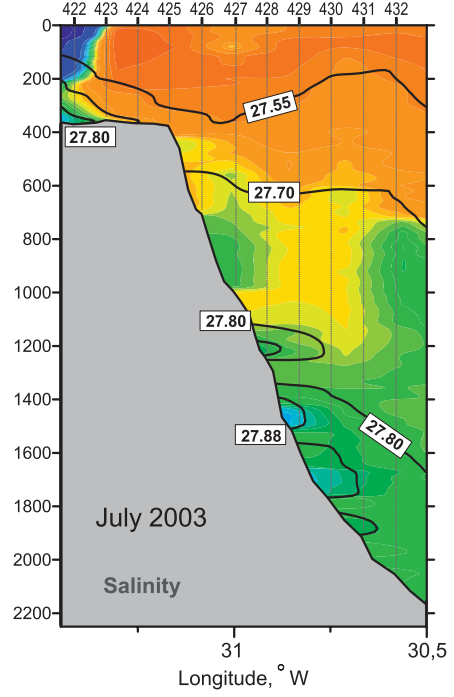

b)

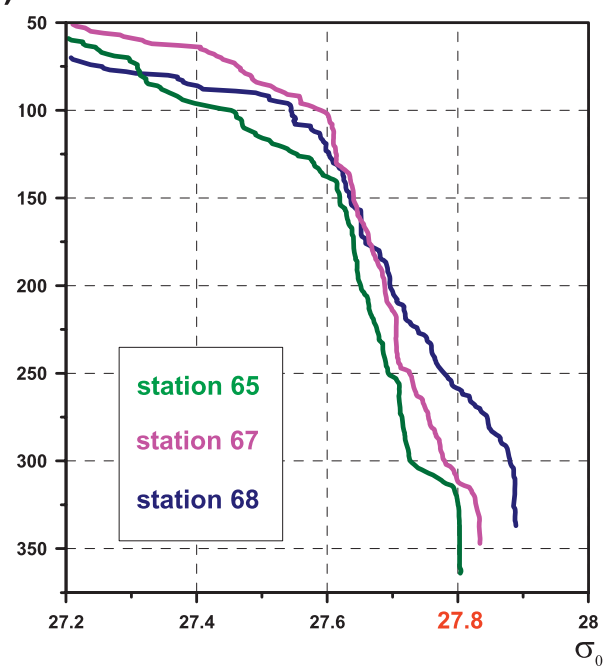

d)

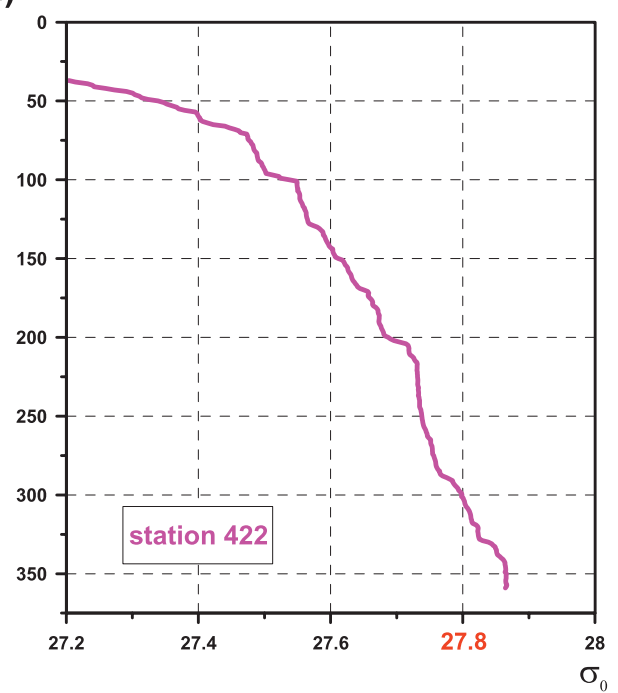

FIG. 4. Potential temperature $\left({ }^{\circ} \mathrm{C}\right.$ ) and salinity observed at the $\mathrm{S} 1$ line in (a) August 2005 and (c) July 2003. The $\sigma_{0}$ isopycnals 27.55 , $27.70,27.80$, and 27.88 are shown as thick black lines; the station locations are marked with the ticks on the top axes. Vertical profiles of potential density $\left(\sigma_{0}\right)$ from individual stations (see the legend) carried out at the shelf in (b) August 2005 and (d) July 2003.

Macrander et al. 2005), which are based on measurements in the deepest channel of the Strait and, hence, do not account for the advection of dense waters over the shelf.

\section{Observed traces of dense shelf water cascading reaching the DWBC}

Given the high density of the densest shelf waters (up to $\sigma_{0}=27.89$ ) observed south of the Denmark Strait at the S1 line, it is expected that, under favorable dynamical conditions, these waters cross the shelf break, cascade down the continental slope and join the DWBC. Indeed, a numerical simulation by Magaldi et al. (2011) suggests that events of dense water spilling off the shelf can occur in various locations southwest of the Denmark Strait and that the descending shelf waters can episodically merge with the deep waters transported by the DWBC. It was suggested that spilling events can be induced by East Greenland barrier winds pushing shelf waters offshore along the bottom (Pickart et al. 2005), by local perturbations in the flow and by eddies associated with dense overflow domes at depth (see Magaldi et al. 2011). Here, we present hydrographic patterns bearing the imprint of shelf water cascading reaching the DWBC in the northern Irminger Sea and report on observed properties of cascading dense waters. 


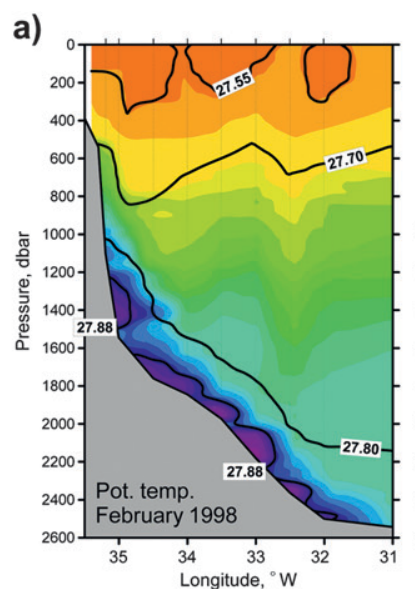

c)

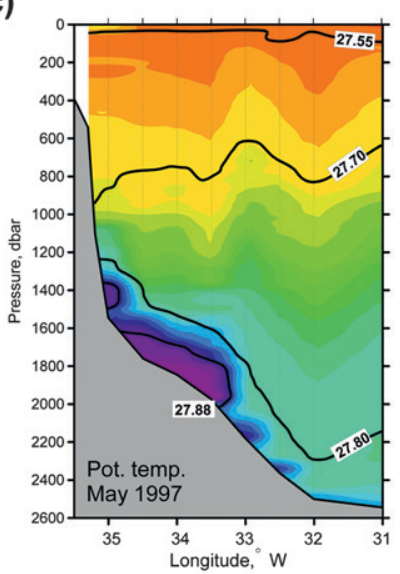

e)

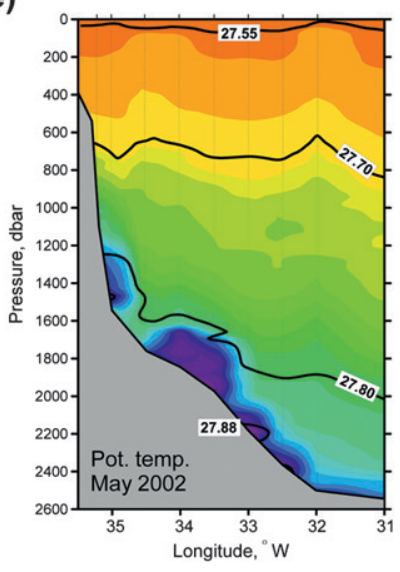

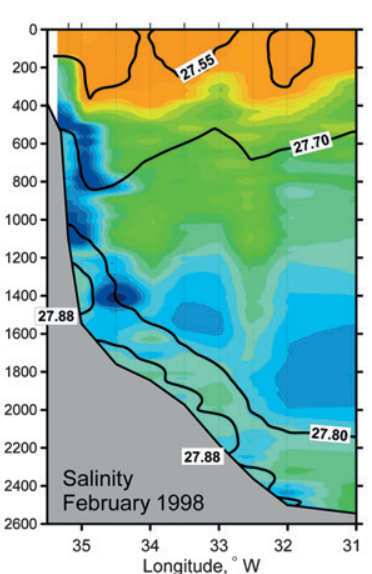
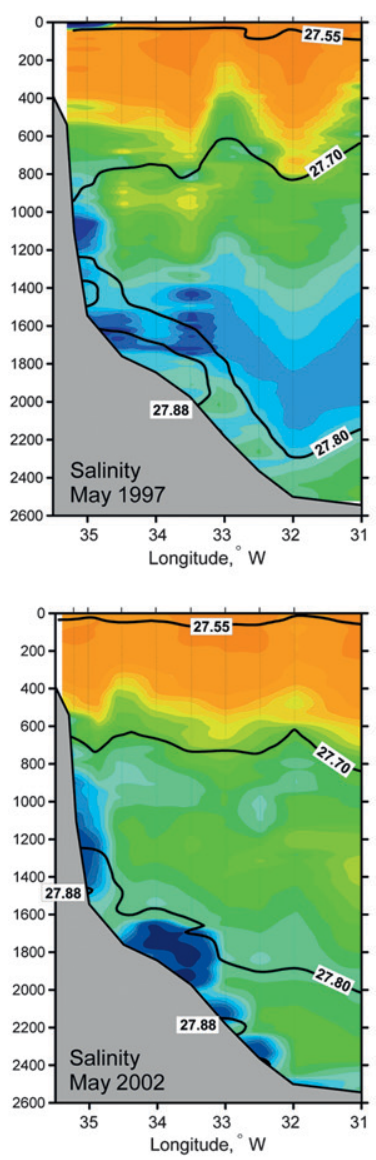

b)

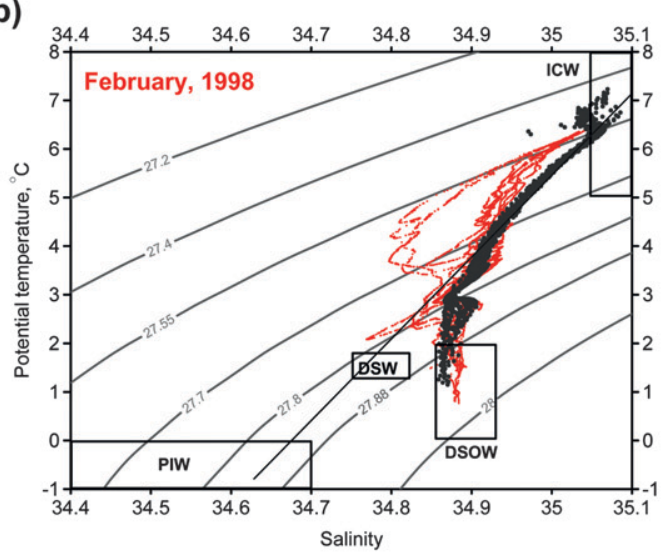

d)

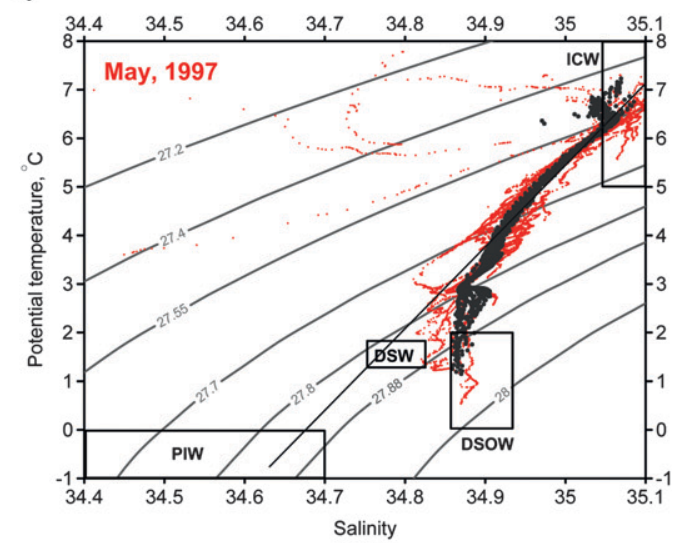

f)

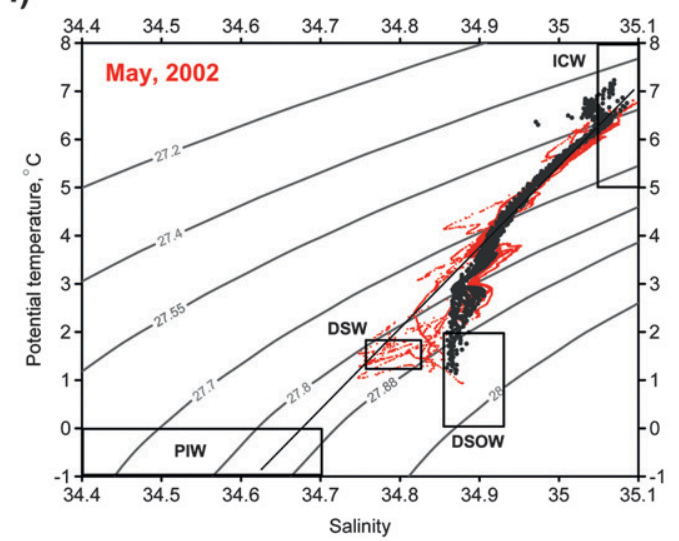

\section{$\theta,{ }^{\circ} \mathrm{C}$}

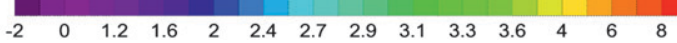

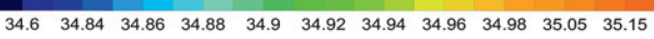

FIG. 5. Potential temperature $\left({ }^{\circ} \mathrm{C}\right.$ ) and salinity observed at the S2 line in (a) February 1998, (c) May 1997, and (e) May 2002. The $\sigma_{0}$ isopycnals $27.55,27.70,27.80$, and 27.88 are shown as thick black lines; the station locations are marked with the ticks on the top axes. The $\theta-S$ diagrams for the data collected at S2 in (b) February 1998, (d) May 1997, and (f) May 2002. In each $\theta-S$ plot, the properties averaged over 11 surveys (see Table 1 ) (black dots) are superimposed. The rectangles denote the typical $\theta-S$ ranges for the following water types: the Irminger Current Water (ICW, $\left.5<\theta<8^{\circ} \mathrm{C}, S>35.05\right)$ (Fogelqvist et al. 2003); DSOW $\left(\theta<2^{\circ} \mathrm{C}, 34.87<S<34.93\right)(\mathrm{Macrander}$ et al. 2007; Dickson et al. 2002); Polar Intermediate Water (PIW, $\theta<0^{\circ} \mathrm{C}, 34.4<S<34.7$ ) (Malmberg 1972; Rudels et al. 1999; Fogelqvist et al. 2003), and Dense Shelf Water (DSW, $1.17<\theta<1.9^{\circ} \mathrm{C}, 34.75<S<34.83$ ) as observed at the S1 line in August 2005 (see Fig. $4 a$ ). 

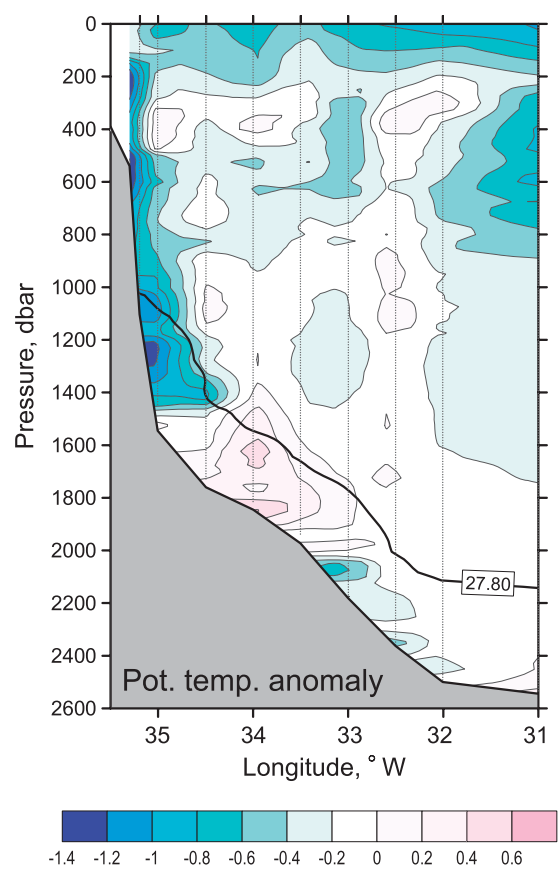
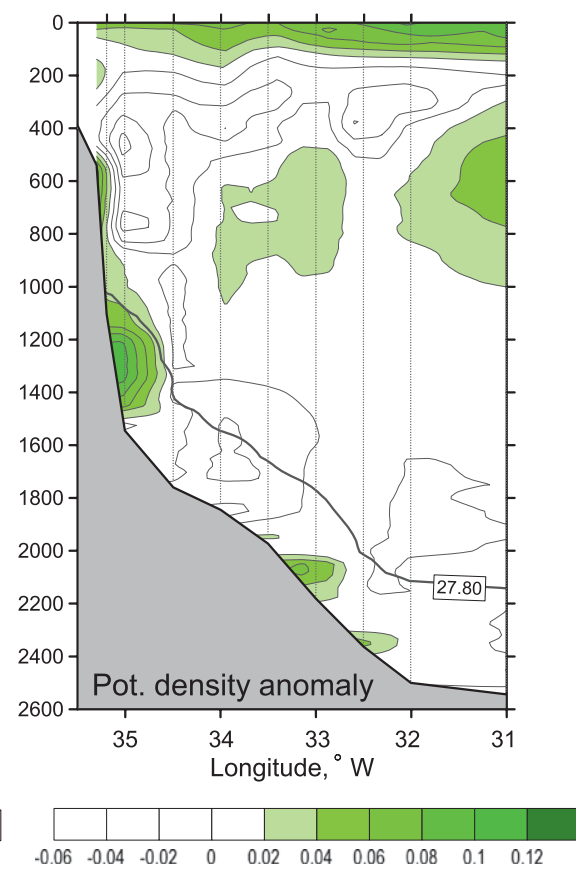

FIG. 6. Potential temperature $\left({ }^{\circ} \mathrm{C}\right)$ and density $\left(\sigma_{0}\right)$ anomalies at the S2 line in February 1998 relative to a mean state computed from the 1997-2003 data (see Table 1) excluding the data from May 1997, February 1998, and May 2002, when the hydrographic signatures of cascading were observed (see section 6). The $\sigma_{0}$ isopycnal 27.80 for February 1998 is superimposed. The station locations are marked with the ticks on the top axes.

Hydrographic data collected at the Faxafloi section $\left(64.3^{\circ} \mathrm{N}\right.$, the S2 line in Fig. 1) support the original hypothesis by Rudels et al. (1999) and the recent modelbased inference by Magaldi et al. (2011) that sinking dense shelf waters can reach great depths and join the DWBC. Indeed, as detailed below, hydrographic traces of the shelf water cascading to depths of more than $1200 \mathrm{~m}$ are seen from the data collected at S2 in May 1997, February 1998, and May 2002 (i.e., from 3 of the 11 repeats of S2, see Table 1).

A spilling of shelf water at $64.3^{\circ} \mathrm{N}$ is evident from the February 1998 salinity section (Fig. 5a) that shows a continuous near-slope low-salinity $(S<34.85)$ tongue extending from depths of $\sim 250$ to $\sim 850 \mathrm{~m}$, and two deeper fresh $(34.76<S<34.85)$ plumes at depths of 900-1200 m and $1300-1500 \mathrm{~m}$. The observed tongue and the two plumes have similar low salinity $(34.76<S<34.85$, Figs. $5 \mathrm{a}, \mathrm{b})$, but different temperatures $\left(2<\theta<5^{\circ} \mathrm{C}\right.$, the deeper plumes are colder, see Figs. 5a,b) and, hence, different densities ranging from $\sigma_{0}=27.6$ to $\sigma_{0}=27.81$ (Fig. 5b). The salinity of the plumes is lower than that of LSW $(S>$ $\left.34.85,2.8<\theta<3.2^{\circ} \mathrm{C}\right)$ and DSOW $\left(S>34.87, \theta<2^{\circ} \mathrm{C}\right)$.

Although the shelf water cascading in February 1998 is not as evident from the potential temperature section as it is from the salinity one (Fig. 5a), the pattern of temperature anomalies in February 1998 relative to the
1997-2003 mean (Fig. 6a) reveals anomalously cold shelf waters descending down the Greenland slope from depths of $\sim 150 \mathrm{~m}$ to $\sim 1450 \mathrm{~m}$ and merging with the DWBC $\left(\sigma_{0}>27.80\right)$. The February 1998 pattern of potential density anomalies (Fig. 6b) confirms that the anomalously cold and fresh waters spilling from the shelf were also anomalously dense. The largest density anomalies (up to about $+0.12 \mathrm{~kg} \mathrm{~m}^{-3}$ ) associated with waters descending from the shelf were found in the DWBC $\left(\sigma_{0}>27.80\right)$ at depths of $\sim 1100-1450 \mathrm{~m}$ (Fig. 6b).

Traces of another spilling event were observed at S2 in May 1997. Penetration of fresh $(34.81<S<34.84)$ and dense $\left(27.69<\sigma_{0}<27.89\right)$ plumes into the LSW and DSOW layers was detected at depths of $800-1750 \mathrm{~m}$ over the East Greenland slope (Fig. 5c). The salinity of these plumes was substantially lower than the salinity of LSW and DSOW. The densest plumes (up to $\sigma_{0}=27.89$ ) are seen as low-salinity lids overlying the more saline and colder DSOW (Figs. 5c).

A near-slope plume of fresh $(S<34.87)$ and dense $\left(27.70<\sigma_{0}<27.90\right)$ water was identified at $\mathrm{S} 2$ from the May 2002 salinity data (Fig. 5e) within the 800-1550-mdepth range, that is, in the LSW and deep water layers. The freshest $(34.81<S<34.84)$ part of the plume (depths of 1200-1500 m) was as dense (up to $\sigma_{0}=27.90$ ) 

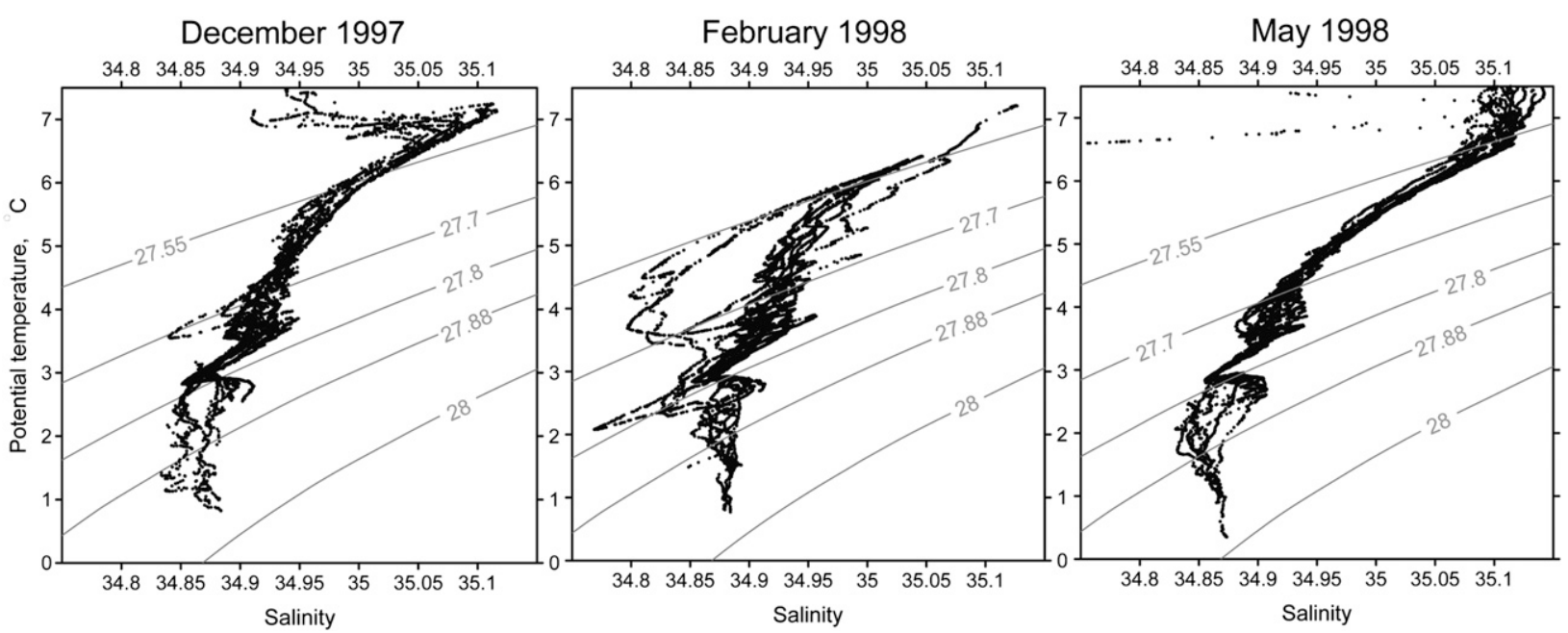

FIG. 7. The $\theta-S$ diagrams for the data collected at the S2 line in December 1997, February 1998, and May 1998.

as the overflow water observed down the slope at depths greater than $1600 \mathrm{~m}$ (Figs. 5e,f).

In each of the three above cases, the densest plumes $\left(27.80<\sigma_{0}<27.90\right)$ penetrated into the deep water layer $\left(\sigma_{0}>27.80\right)$ and thus transferred fresh "signals" from the upper levels into the DWBC. Since in none of these three cases the layer of dense waters $\left(\sigma_{0}>27.80\right)$ extended from the shelf to the lower part of the slope, we conclude that the densest $\left(\sigma_{0}>27.80\right)$ fresh plumes observed at S2 descended down the slope upstream of S2. This implies that cascading of dense shelf waters capable to merge with the DWBC occurs in between the Denmark Strait and $\sim 64^{\circ} \mathrm{N}$, in agreement with the hypothesis by Rudels et al. (1999). The fact that the dense waters $\left(\sigma_{0}>27.80\right)$ spilling from the shelf were observed at S2 on the midslope $(\sim 1000$ $1500 \mathrm{~m}$ ) above the "classical" DSOW (depths of more than $1500-1600 \mathrm{~m}$ ) corroborates earlier finding that the densest waters $\left(\sigma_{0}>27.80\right)$ occasionally transported at middepths $(<1500 \mathrm{~m})$ by the Greenland Spill Jet at $65^{\circ}-66^{\circ} \mathrm{N}$ (see Brearley et al. 2012; e.g., their Fig. $6 c)$ contain a substantial fraction of waters originating from the shelf.

Figure 7 displays the $\theta-S$ diagrams based on the data collected a few months apart at S2 in December 1997, February 1998, and May 1998. The data from December 1997 and May 1998 do not show any remarkable traces of shelf water cascading. The data obtained in February 1998 do show such traces, as discussed above (Fig. 5b). This, along with the fact that the signatures of dense shelf water cascading were observed only in 3 of the 11 surveys, confirms that shelf water cascading in the northwestern Irminger Sea is a transient rather than a continuous phenomenon.
Although the apparent short duration of cascading events makes them hard to observe from research vessels, the data considered herein along with the results from earlier studies (Rudels et al. 1999, 2002; Pickart et al. 2005; Brearley et al. 2012) suggest that the cascading may occur throughout the year. Earlier, the events of shelf water cascading in the northwestern Irminger Sea were observed down to the intermediate levels $\left(\sigma_{0}<27.80\right)$ in August and September (Rudels et al. 1999; Pickart et al. 2005; Brearley et al. 2012). Here, the occurrence of shelf water cascading down to the deep levels $\left(\sigma_{0}>27.80\right)$ is inferred from the data collected in February and May.

\section{Likely link between the low-salinity anomalies in the DWBC at $60^{\circ} \mathrm{N}$ and the upstream shelf water cascading}

In section 4, we hypothesized that the anomalously fresh "signals" repeatedly observed in the DWBC at $\sim 60^{\circ} \mathrm{N}$ can be associated with an upstream descent of fresh dense waters from the shelf. As discussed in Section 6 , the descent of dense shelf water does episodically occur north of $\sim 64^{\circ} \mathrm{N}$ and the densest fresh plumes sinking down the East Greenland slope are found in the $\operatorname{DWBC}\left(\sigma_{0}>27.80\right)$.

According to Dickson et al. (2008), it takes 1 to 2 months for waters carried by the DWBC from the northern Irminger Sea to reach $60^{\circ} \mathrm{N}$. Therefore, if lowsalinity anomalies produced by shelf water cascading were observed at $64.3^{\circ} \mathrm{N}$ in May, they would be expected to appear at $\sim 60^{\circ} \mathrm{N}$ in June-July. The comparison below of the data collected at $64.3^{\circ} \mathrm{N}$ in May 2002 and 2003 with the data collected at $60^{\circ} \mathrm{N}$ in June 2002 and July 2003 (Fig. 8) implies that it is likely to be the case. 
$64,3^{\circ} \mathrm{N}$ section

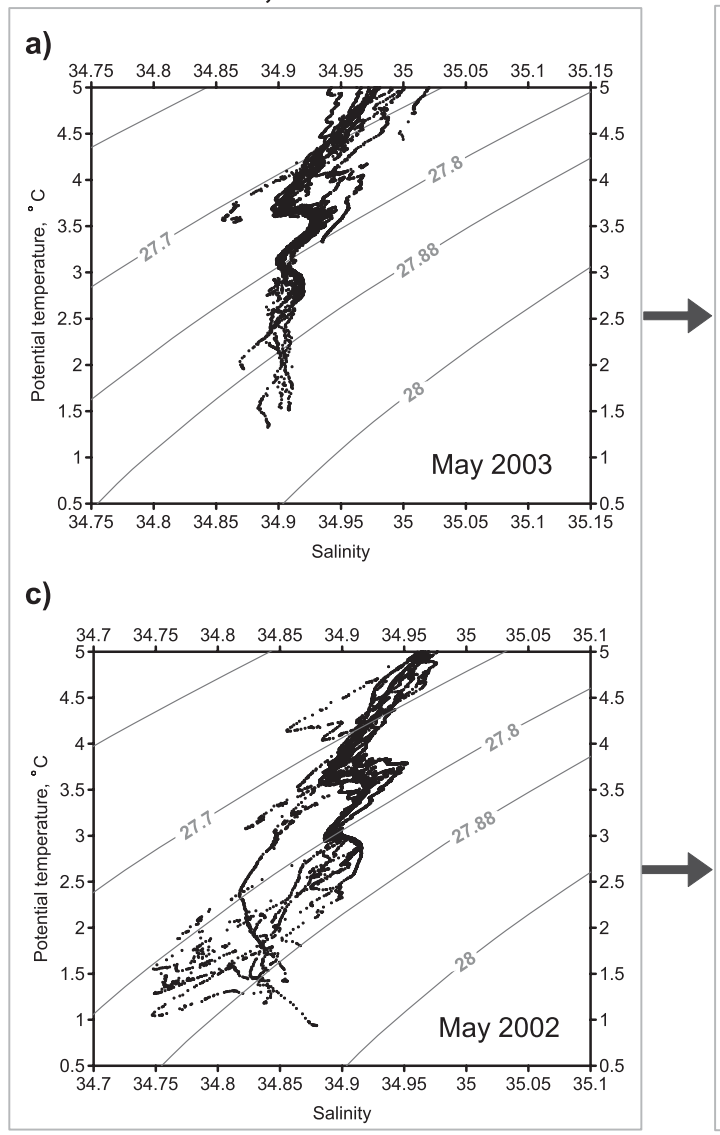

$60^{\circ} \mathrm{N}$ section

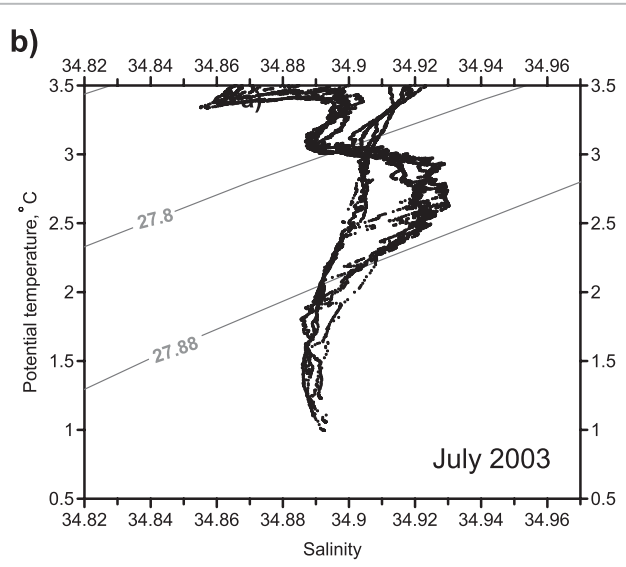

d)

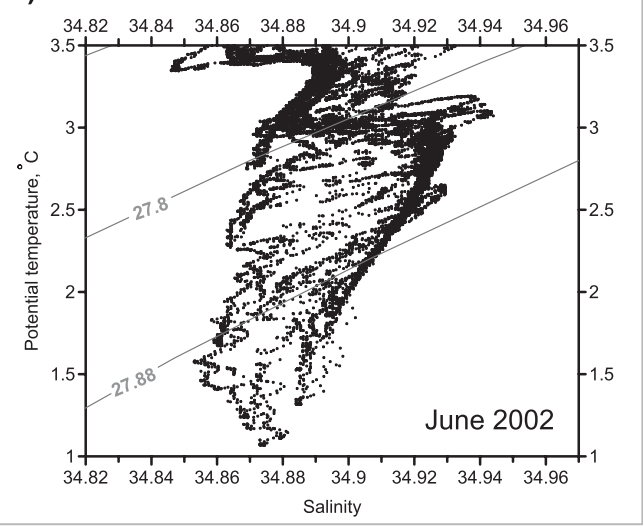

FIG. 8. The $\theta-S$ diagrams for the data collected at the S2 line in (a) May 2003 and (c) May 2002 and at the S3 line in (b) July 2003 and (d) June 2002.

The $\theta-S$ diagram based on the $64.3^{\circ} \mathrm{N}$ data from May 2003 (Fig. 8a) shows the absence of distinct low-salinity anomalies, which could be associated with shelf water cascading. The data obtained downstream, at $60^{\circ} \mathrm{N}, \sim 1.5$ months later (Fig. 8b) also indicate the absence of anomalously fresh plumes in the deep water layer $\left(\sigma_{0}>\right.$ 27.80). In 2002, the situation was radically different (Figs. 8c,d). The $\theta-S$ diagram based on the data obtained at $64.3^{\circ} \mathrm{N}$ in May 2002 (Fig. 8c) indicates the presence of low-salinity anomalies $\left(S<34.87, \sigma_{0}>27.80\right)$ associated with the injection of dense freshwater from the shelf (see section 6, Fig. 5e). A month later, during the Ovide cruise a near-slope anomalously freshwater was observed in the DWBC $\left(\sigma_{0}>27.80\right)$ at $60^{\circ} \mathrm{N}$ at depths of up to $\sim 1600 \mathrm{~m}$ (Figs. 3a and $8 \mathrm{~d}$ ). This water at $60^{\circ} \mathrm{N}$ was $\sim 0.1$ saltier and $\sim 1^{\circ} \mathrm{C}$ warmer than that observed in May 2002 at $64.3^{\circ}$ N. Following Lauderdale et al. (2008, see their section 2.3), we estimated the intensity of along-path diapycnal mixing required to explain the increase in temperature and salinity of the near-slope freshwater in between the $64.3^{\circ}$ and $60^{\circ} \mathrm{N}$ sections. A diapycnal mixing rate of the order of $10^{-3} \mathrm{~m}^{2} \mathrm{~s}^{-1}$ was estimated in between the two sections, which is typical of values reported for the WBC close to the East Greenland slope (Lauderdale et al. 2008; Kokoszka 2012, his Fig. 4.14). Therefore, the fresh near-slope water observed in the DWBC at $60^{\circ} \mathrm{N}$ in June 2002 might represent a product of along-path mixing of the dense $\left(\sigma_{0}>\right.$ 27.80) anomalously fresh near-slope water, observed at $64.3^{\circ} \mathrm{N}$ a month earlier, with warmer and saltier ambient waters transported in the WBC at the intermediate and deep levels.

The above comparison provides an argument in support of the hypothesis that the low-salinity anomalies occasionally observed in the DWBC at $60^{\circ} \mathrm{N}$ (in $40 \%$ of the cases, see Section 4) are, at least in part, caused by the upstream cascading of dense fresh shelf water. The argument should be regarded as tentative, though, since the spilling events are localized both in time and space, and therefore we cannot assert that low-salinity signals seen from the data collected at $64.3^{\circ}$ and $60^{\circ} \mathrm{N}$ in 2002 were associated with the same spilling event. 


\section{On the contribution of shelf water cascading to the DWBC transport}

The Denmark Strait Overflow feeds the DWBC in the Irminger Sea with $\sim 3 \mathrm{~Sv}$ of dense cold waters $\left(\sigma_{0}>27.80\right)$ passing through the deepest part of the Strait (e.g., Macrander et al. 2005). According to Sarafanov et al. (2012), in the 2000s the DWBC transport $\left(\sigma_{0}>\right.$ 27.80) increased from $\sim 3 \mathrm{~Sv}$ at the Denmark Strait to $\sim 10 \mathrm{~Sv}$ at $60^{\circ} \mathrm{N}$ mostly because of the entrainment from the upper levels $\left(\sigma_{0}<27.80\right)$. The results of the present analysis support the hypothesis by Rudels et al. (1999) that the fresh dense plumes descending from the shelf south of the Denmark Strait occasionally merge with the DWBC. Accordingly, it is very likely that shelf water cascading in the northern Irminger Sea is responsible for a part of the increase in the transport of the DWBC along its path to $60^{\circ} \mathrm{N}$.

The lack of velocity measurements limits our ability to estimate transports associated with the shelf-derived dense waters observed in the DWBC at the S2 line (see Section 6). Nevertheless, the possible contribution of shelf water cascading to the DWBC transport can be tentatively estimated from the data collected downstream, at the S3 line, in June 2002 and June 2004 during the Ovide cruises (see Table 1). In these two cruises, the anomalously fresh and oxygen-rich waters were observed in the DWBC in the ISOW density class $\left(27.80<\sigma_{0}<27.88\right)$ (see section 4 , Fig. 3). These waters likely originated from the shelf, as we suggested above (see section 7), and the associated transports can thus be considered as a tentative quantitative measure of the transient effect of upstream shelf water cascading on the DWBC transport.

Absolute transports across the Ovide section in 2002 and 2004 have recently been estimated by Lherminier et al. $(2007,2010)$ by combining CTD and vesselmounted ADCP data collected in the cruises. The DWBC transport $\left(\sigma_{0}>27.80\right)$ was estimated at $8.2 \pm$ $1.0 \mathrm{~Sv}$ in June 2002 and $11.2 \pm 1.7 \mathrm{~Sv}$ in June 2004 (Lherminier et al. 2007, 2010). Using the absolute velocity fields from Lherminier et al. (2010), we quantified, for each of the two surveys, the fraction of the DWBC transport associated with the anomalously fresh $(S<34.88)$ and oxygenated $\left(290<\mathrm{O}_{2}<305 \mu \mathrm{mol} \mathrm{kg}^{-1}\right)$ waters in the ISOW density class $\left(27.80<\sigma_{0}<27.88\right)$. This fraction was estimated at $\sim 26 \%(2.1 \pm 0.3 \mathrm{~Sv})$ in 2002 and $23 \%(2.6 \pm 0.3 \mathrm{~Sv})$ in 2004 . Accordingly, about $25 \%$ of the DWBC transport at $60^{\circ} \mathrm{N}$ in June 2002 and June 2004 was associated with the fresh near-slope waters likely originating from the East Greenland shelf in the northern Irminger Sea.

It should be emphasized that the above tentative estimate based on data from the two synoptic sections does not imply that $\sim 25 \%$ of the time-mean DWBC transport at $60^{\circ} \mathrm{N}$ is due to shelf water cascading. The duration of cascading events is unknown, and in $60 \%$ of the cases considered in this study, no hydrographic signatures of upstream cascading were observed at $60^{\circ} \mathrm{N}$. Therefore, the time-mean contribution of cascading to the DWBC transport cannot be reliably estimated from the data used herein. What the above estimate does imply is that the transient contribution of an individual cascading event in the northern Irminger Sea to the DWBC transport at Cape Farewell can be as large as $\sim 25 \%$ and, thus, shelf water cascading in the northern Irminger Sea is very likely to be one of the important mechanisms behind the DWBC transport variability.

\section{Conclusions}

The analysis of hydrographic data collected in the northwestern Irminger Sea $\left(65^{\circ}-66^{\circ} \mathrm{N}\right)$ demonstrated that the East Greenland Current $\sim 200 \mathrm{~km}$ south of the Denmark Strait occasionally carries shelf waters as dense as the overflow-derived deep waters transported by the DWBC $\left(\sigma_{0}>27.80\right)$. Hydrographic traces of cascading of dense shelf waters down the East Greenland slope were found at $64.3^{\circ} \mathrm{N}$ in 3 of the 11 surveys conducted in 1997-2003. In all 3 cases, the densest fresh plumes were observed within the DWBC $\left(\sigma_{0}>27.80\right)$. We suggest that the low salinity anomalies originating from the shelf can be traced in the DWBC as far downstream as $60^{\circ} \mathrm{N}$, where the anomalously fresh oxygenated plumes are repeatedly observed (in $40 \%$ of surveys) in the ISOW $\left(27.80<\sigma_{0}<27.88\right)$ and DSOW $\left(\sigma_{0}>27.88\right)$ density classes.

The results of the present analysis along with the results from earlier studies (Rudels et al. 1999; 2002; Pickart et al. 2005; Brearley et al. 2012) show that shelf water cascading in the northern Irminger Sea is an intermittent process occurring in all seasons of the year. This implies that, despite the apparent short duration of a particular cascading event, the cumulative contribution of such events to the thermohaline variability and southward export of the deep waters in the WBC can be considerable. Our tentative estimate based on data from two synoptic surveys suggests that the transient contribution of a cascading event in the northern Irminger Sea to the DWBC transport at Cape Farewell can be as large as $\sim 25 \%$.

Acknowledgments. We thank Steingrímur Jónsson and Andreas Macrander for helpful comments. We thank all who contributed to the hydrographic data processing. Our special thanks to Hendrik M. van Aken for the data collected on board the R/V Pelagia. The 
editor and two anonymous reviewers are gratefully acknowledged for their constructive comments. The study was supported by the Russian Ministry of Education and Science under the "World Ocean" Federal Programme (Contract 01.420.1.2.0001), the RFBR Grants 10-0500029, 11-05-00555, and 12-05-91056-CNRS, and the Russian President Grants MK-1636.2011.5 and MK5357.2012.5. H. Mercier is supported by the French National Center for Scientific Research (CNRS), P. Lherminier by the French Institute for Marine Science (Ifremer), and N. Daniault by the European University of Brittany.

\section{REFERENCES}

Bacon, S., 1998: Decadal variability in the outflow from the Nordic seas to the deep Atlantic Ocean. Nature, 394, 871-874.

Brearley, J. A., R. S. Pickart, H. Valdimarsson, S. Jonsson, R. W. Schmitt, and T. W. N. Haine, 2012: The East Greenland Boundary Current system south of Denmark Strait. Deep-Sea Res. I, 63, 1-19.

Dickson, R. R., and J. Brown, 1994: The production of North Atlantic Deep Water: Sources, rates, and pathways. J. Geophys. Res., 99, 12 319-12 341.

_- I. Yashayaev, J. Meincke, B. Turrell, S. Dye, and J. Holfort, 2002: Rapid freshening of the deep North Atlantic Ocean over the past four decades. Nature, 416, 832-837.

_- and Coauthors, 2008: The overflow flux west of Iceland: Variability, origins and forcing. Arctic-Subarctic Ocean Fluxes: Defining the Role of the Northern Seas in Climate, R. Robert et al., Eds., Springer, 443-474.

Falina, A., A. Sarafanov, and A. Sokov, 2007: Variability and renewal of Labrador Sea Water in the Irminger Basin in 19912004. J. Geophys. Res., 112, C01006, doi:10.1029/2005JC003348.

Fogelqvist, E., J. Blindheim, T. Tanhua, S. Osterhus, E. Buch, and F. Rey, 2003: Greenland-Scotland overflow studied by hydro-chemical multivariate analysis. Deep-Sea Res. I, 50, 73-102.

Girton, J. B., and T. B. Sanford, 2003: Descent and modification of the overflow plume in the Denmark Strait. J. Phys. Oceanogr., 33, 1351-1364.

Holfort, J., and T. Albrecht, 2007: Atmospheric forcing of salinity in the overflow of Denmark Strait. Ocean Sci., 3, 411-416.

Holliday, N. P., S. Bacon, J. T. Allen, and E. L. McDonagh, 2009: Circulation and transport in the western boundary currents at Cape Farewell, Greenland. J. Phys. Oceanogr., 39, 18541870.

Käse, R. H., J. B. Girton, and T. B. Sanford, 2003: Structure and variability of the Denmark Strait Overflow: Model and observations. J. Geophys. Res., 108, 3181, doi:10.1029/ 2002JC001548.

Keike, D., and M. Rhein, 2006: Variability of the overflow water transport in the western subpolar North Atlantic, 1950-97. J. Phys. Oceanogr., 36, 435-456.

Kokoszka, F., 2012: Estimations du mélange vertical le long de sections hydrologiques en Atlantique nord. Ph.D. thesis, Universitéde Bretagne Occidentale, 191 pp.

Lauderdale, J. M., S. Bacon, A. C. Naveira Garabato, and N. P. Holliday, 2008: Intensified turbulent mixing in the boundary current system of southern Greenland. Geophys. Res. Lett., 35, L04611, doi:10.1029/2007GL032785.
Lazier, J. R. N., R. Hendry, A. Clarke, I. Yashayaev, and P. Rhines, 2002: Convection and restratification in the Labrador Sea, 1990-2000. Deep-Sea Res., 49, 1819-1835.

Lherminier, P., H. Mercier, C. Gourcuff, M. Alvarez, S. Bacon, and C. Kermabon, 2007: Transports across the 2002 GreenlandPortugal Ovide section and comparison with 1997. J. Geophys. Res., 112, C07003, doi:10.1029/2006JC003716.

$\longrightarrow,-$, T. Huck, C. Gourcuff, F. F. Perez, P. Morin, A. Sarafanov, and A. Falina, 2010: The Atlantic meridional overturning circulation and the subpolar gyre observed at the A25OVIDE section in June 2002 and 2004. Deep-Sea Res., 57, 1374-1391.

Macrander, A., U. Send, H. Valdimarsson, S. Jónsson, and R. H. Käse, 2005: Interannual changes in the overflow from the Nordic Seas into the Atlantic Ocean through Denmark Strait. Geophys. Res. Lett., 32, L06606, doi:10.1029/2004GL021463.

— , R. H. Käse, U. Send, H. Valdimarsson, and S. Jónsson, 2007: Spatial and temporal structure of the Denmark Strait Overflow revealed by acoustic observations. Ocean Dyn., 57, 75-89.

Magaldi, M. G., T. W. N. Haine, and R. S. Pickart, 2011: On the nature and variability of the East Greenland Spill Jet: A case study in summer 2003. J. Phys. Oceanogr., 41, 23072327.

Malmberg, S. A., 1972: Intermediate Polar Water in the Denmark Strait-"overflow." August 1971. ICES Conf. Meet., 6, 44-60.

Nansen, F., 1912: Das bodenwasser und die abkuhlung des meeres. Int. Rev. Gesamten Hydrobiol. Hydrograph., 1, 1-42.

Pickart, R. S., M. A. Spall, M. H. Ribergaard, G. W. K. Moore, and R. F. Milliff, 2003: Deep convection in the Irminger Sea forced by the Greenland tip jet. Nature, 424, 152-156.

— D. J. Torres, and P. S. Fratantoni, 2005: The East Greenland spill jet. J. Phys. Oceanogr., 35, 1037-1053.

Rudels, B., P. Eriksson, H. Grönvall, R. Hietala, and J. Launiainen, 1999: Hydrographic observations in Denmark Strait in Fall 1997, and their implications for the entrainment into the overflow plume. Geophys. Res. Lett., 26, 1325-1328.

— E. Fahrbach, J. Meincke, G. Budeus, and P. Eriksson, 2002: The East Greeenland Current and its contribution to the Denmark Strait overflow. ICES J. Mar. Sci., 59, 1133-1154.

Sarafanov, A., 2009: On the effect of the North Atlantic Oscillation on temperature and salinity of the subpolar North Atlantic intermediate and deep waters. ICES J. Mar. Sci., 66, 1448 1454, doi:10.1093/icesjms/fsp094.

_ A. Sokov, A. Demidov, and A. Falina, 2007: Warming and salinification of intermediate and deep waters in the Irminger Sea and Iceland Basin in 1997-2006. Geophys. Res. Lett., 34, L23609, doi:10.1029/2007GL031074.

— A. Falina, H. Mercier, P. Lherminier, and A. Sokov, 2009: Recent changes in the Greenland-Scotland overflow-derived water transport inferred from hydrographic observations in the southern Irminger Sea. Geophys. Res. Lett., 36, L13606, doi:10.1029/2009GL038385.

- H. Mercier, A. Falina, A. Sokov, and P. Lherminier, 2010: Cessation and partial reversal of deep water freshening in the northern North Atlantic: Observation-based estimates and attribution. Tellus, 62A, 80-90, doi:10.1111/j.1600-0870.2009.00418.x.

_ , and Coauthors, 2012: Mean full-depth summer circulation and transports at the northern periphery of the Atlantic Ocean in the 2000s. J. Geophys. Res., 117, C01014, doi:10.1029/ 2011JC007572.

Smith, P. C., 1976: Baroclinic instability in the Denmark Strait overflow. J. Phys. Oceanogr., 6, 355-371. 
Sutherland, D. A., and R. S. Pickart, 2008: The East Greenland Coastal Current: Structure, variability, and forcing. Prog. Oceanogr., 78, 58-77.

Tanhua, T., K. A. Olsson, and E. Jeansson, 2005: Formation of Denmark Strait overflow water and its hydro-chemical composition. J. Mar. Syst., 57, 264-288.

Våge, K., and Coauthors, 2011a: The Irminger Gyre: circulation, convection, and interannual variability. Deep-Sea Res. I, 58, 590-614, doi:10.1016/j.dsr.2011.03.001.

R. S. Pickart, M. A. Spall, H. Valdimarsson, S. Jonsson, D. J. Torres, S. Osterhus, and T. Eldevik, 2011b: Signifi- cant role of the North Icelandic Jet in the formation of Denmark Strait overflow water. Nat. Geosci., 4, 723-727, doi:10.1038/ngeo1234.

Yashayaev, I., and R. Dickson, 2008: Transformation and fate of overflows in the Northern North Atlantic. Arctic-Subarctic Ocean Fluxes, R. Dickson, J. Meincke, and P. Rhines, Eds., Springer, 505-526, doi:10.1007/978-1-4020-6774-7_22.

H. van Aken, P. Holliday, and M. Bersch, 2007: Transformation of the Labrador Sea Water in the subpolar North Atlantic. Geophys. Res. Lett., 34, L22605, doi:10.1029/ 2007GL031812. 